ЦПК після слів «... ухвала суду» доцільно доповнити словами «судовий наказ, виданий відповідно до пунктів 4 і 5 частини 1 статті 161 цього Кодексу».

Виходячи 3 наведеного, можна зробити висновок - процедура перегляду судових рішень за нововиявленими обставинами є неординарною, має певні особливості, тому суду необхідно ретельного з'ясування наявності нововиявлених обставин для вирішення питання про відкриття провадження у справі. При вирішенні таких питань суд має використовувати практику ЄСПЛ, звертати увагу щодо забезпечення застосування принципів правової визначеності та res judicata відповідно 3 національним законодавством та міжнародними стандартами. Подальше вдосконалення цивільного процесуального законодавства щодо перегляду судових рішень за ново- виявленими обставинами, усунення колізійних норм сприятиме реалізації завдань цивільного судочинства, конституційного права на судовий захист.

\title{
Література:
}

1. Ткачук О. С. Проблеми реалізації судової влади у цивільному судочинстві: монографія / О. С. Ткачук. - Х.: Право, 2016. - 600 с.

2. Сакара Н. Ю. Проблема доступності правосуддя у цивільних справах: монографія / Н.Ю. Сакара. - Х.: Право, 2010. - С. 52-53.

DOI https://doi.org/10.30525/978-9934-26-074-2-15

\section{ПРЕДСТАВНИЦЬКА ПРАВОСУБ'ЄКТНІСТЬ ЯК ПЕРЕДУМОВА ВИНИКНЕННЯ ВІДНОСИН ПРЕДСТАВНИЦТВА}

\author{
Гелецька I. O. \\ кандидат юридичних наук, \\ заступник директора з навчальної, наукової роботи \\ та міжнародного співробітництва \\ Галицького коледжу імені В 'ячеслава Чорновола \\ м. Тернопіль, Україна
}

Одним із елементів змісту цивільної правоздатності є здатність набувати і здійснювати цивільні права та виконувати цивільні обов'язки через дії представника. Межі цієї здатності визначаються в цивільноправових нормах прямо чи опосередковано. Насамперед іiі обмежено колом тільки тих дій, для здійснення яких необхідна наявність дієздатності, тобто правочинів. Юридичні вчинки, а також фактичне 64 
користування майном можуть здійснюватися суб'єктами цивільного права, у тому числі повністю недієздатними. Юридичний вчинок - це діяльність будь-якої правоздатної фізичної особи. Вчинки створюють правові наслідки незалежно від того, чи усвідомлювала особа їх правове значення. Сдиною умовою $є$ наявність відповідного психічного стану особи, що дозволив би здійснити його. Тому здійснення юридичних вчинків через представника неможливе, оскільки діяти від імені іншої особи можна лише з наміром створення певних юридичних наслідків.

Представник - особа, яка в силу наявних у неї повноважень вчиняє правочини та інші юридичні дії від імені особи, яку представляє. Правовідносини представництва здійснюються цілеспрямованими юридичними діями представника, тому в якості останнього можуть виступати лише дієздатні суб'єкти. Відповідно здатність мати права та обов'язки представника i здатність своїми цілеспрямованими діями створювати правові наслідки для іншої особи виступають як єдина представницька правосуб'єктність.

Хоча за змістом ч. 1 ст. 32 Цивільного Кодексу України (далі - ЦК України) [1] неповнолітні у віці від 14 до 18 років мають право особисто вчиняти будь-які правочини, вважаємо, що вони не можуть укладати договори в якості представників навіть за згодою своїх піклувальників. Підлітку довелось би запитувати дозвіл піклувальника не лише на укладання договору доручення, але i на дії 3 реалізації повноваження, які, як правило, також є правочинами. За такої ситуації дії представника, а також і сама можливість їх здійснення в значній мірі визначалися б волею його піклувальника - особи, не уповноваженої на представництво, що суперечить особисто-довірчому характеру відносин при добровільному представництві.

Представник відповідає перед особою, яку представляє за різного роду упущення, що спричинили збитки. Створювати для неповнолітніх умови, які можуть призвести до їх майнової відповідальності, недоцільно. Неповнолітні наділяються дієздатністю у власних інтересах, для забезпечення можливості набувати та здійснювати власні права i виконувати обов'язки, а не для того, щоб діяти в інтересах інших осіб. Зрештою, відсутність у неповнолітніх представників зрілої волі та достатнього життєвого досвіду містить у собі значний ризик для особи, яку вони представляють.

Нездатність неповнолітнього в окремих випадках виступати в якості законного представника прямо випливає з закону: усиновителями та опікунами не можуть бути особи, які не мають повної цивільної дієздатності (ч.2 ст. 63 ЦК України і ст. 211 Сімейного Кодексу України [2]). Винятки з цього правила зроблені лише для неповнолітніх батьків, 
що діють в якості представників своїх малолітніх дітей. Даючи дозвіл на вчинення правочину від імені дитини неповнолітнім батькам, орган опіки та піклування повинен особливо перевіряти відповідність такого правочину інтересам особи, яку представляють.

Заперечення представницької правосуб'єктності поширюється і на осіб, обмежених у дієздатності (ст. 37 ЦК України), зокрема, коли мова іде про представництво у сфері майнових правовідносин. За межами майнової сфери обмежено дієздатних необхідно визнати здатними набувати та здійснювати права і обов'язки представників.

Закон визнає за обмежено дієздатними можливість виступати в якості законних представників своїх малолітніх дітей. Такий висновок випливає 3 того, що разом з обмеженням у дієздатності закон не передбачає встановлення опіки над дітьми даної особи навіть у відсутність іншого 3 батьків. Очевидно, краще було би, аби обмеження особи у дієздатності за правилами ст. 37 ЦК України мало б наслідком і припинення відносин представництва між обмежено дієздатним та його малолітніми дітьми у сфері майнових прав та обов'язків останніх незалежно від наявності іншого з батьків. Обмеження у дієздатності одного з батьків за відсутності іншого, а так само обмеження у дієздатності обох батьків має супроводжуватися встановленням опіки і призначенням опікуна над майном їх малолітніх дітей. Такий висновок обумовлюється цілями обмеження дієздатності у судовому порядку - забезпечення інтересів не лише цієї особи, але і iї сім'ї. Заборона обмежено дієздатному представляти своїх дітей в їх майнових правах та обов'язках захищає останніх від можливих зловживань 3 боку їх обмежено дієздатних батьків та третіх осіб. Обмежено дієздатні повинні бути позбавлені здатності набувати та здійснювати майнові права та обов'язки своїх дітей навіть за згодою своїх піклувальників. Коло осіб, які можуть виступати в якості законних представників, вичерпно визначено в законі, як і підстави, в силу яких особа може стати законним представником. Визнання за обмежено дієздатними права вчиняти від імені дітей правочини за згодою піклувальника призвело б до того, що при представництві вирішальну роль відігравала воля піклувальника, який не уповноважений на представництво дітей свого підопічного.

Таким чином, правосуб'єктність представника мають тільки повністю дієздатні громадяни - у межах якої вони вважаються здатними до самостійного вчинення правочинів.

Відповідно до ч. 1 ст. 238 ЦК України представник може бути уповноважений на вчинення лише тих правочинів, право на вчинення яких має особа, яку він представляє. Для добровільного представництва це правило $є$ цілком виправданим. Якщо ж проаналізувати вказану норму 
3 позиції законного представництва, можна прийти до висновку, що опікун, призначений малолітній особі, уповноважується на вчинення лише дрібних побутових правочинів. Проаналізована дефініція (ч. 1 ст. 238 ЦК України), на нашу думку, має не зовсім вдалу конструкцію, а тому потребує законодавчого перегляду ії змісту, щоб не виникало жодних сумнівів при ії тлумаченні.

Межі правоздатності особи-представника визначаються ч. 2 ст. 238 ЦК України, за умовами якої представник не може вчиняти правочин, який відповідно до його змісту може бути вчинений лише особисто тією особою, яку він представляє (складання заповіту, укладання договору довічного утримання, укладання шлюбу тощо). Це положення закону визначає межі здатності виступати через представника при набутті та реалізації не тільки цивільних, але і інших прав та обов'язків. Межі здатності діяти через представника у кожній галузі права залежать від характеру прав та обов'язків, які можуть мати ії суб'єкти: чим більше прав та обов'язків, тісно пов'язаних з особою, тим вужче, як наслідок, сфера застосування представництва у даній галузі права.

Дієздатність представника сумнівів не викликає, оскільки правочин вчиняється діями останнього хоча і від імені особи, яку він представляє. Спірним є питання про те, чия воля виражається у правочині, який вчиняється однією особою від імені іншої, - воля представника, особи, яку представляють, чи їх обох.

Питання про «належність» волі набуває практичного значення при встановленні вини, недобросовісності, пороків волі та інших суб'єктивних моментів, що є важливими для дійсності правочину. При законному представництві усі суб'єктивні моменти «зосереджуються» у поведінці представника, а спрямованість і зміст волі представника визначаються волею законодавця та інтересами особи, яку представляють. При добровільному представництві для дійсності представницького правочину суттєвими є суб'єктивні моменти, які характерні як поведінці представника, так i особи, яку представляють. А це передбачає дослідження долі фактичної участі кожного 3 них у формуванні волі та іiі виявленні у правочині. Так, якщо представник вчинив правочин під впливом обману, насильства (ст.ст. 230, 231 ЦК України), помилки (ст. 229 ЦК України), вимагати визнання його недійсним можуть і представник - суб'єкт дії, і особа, яку представляють - носій прав та обов'язків за правочином. Якщо ж представник, вчиняючи правочин, не знав про обставини, які мають значення для визнання його недійсним, а особа, яку представляють була проінформована про них, то вирішальне значення має поінформанність останньої. 
Уповноважуючи представника на вчинення правочину, особа, яку представляють тим самим бере участь в формуванні, і у волевиявленні на вчинення правочину перед третіми особами. Воля особи, яку представляють фіксується у відповідному документі, доведеному до відома третіх осіб, - довіреності, i, виражена перед третіми особами у даному випадку не безпосередньо, а побічним шляхом та обумовлює виникнення правових наслідків щодо третьої особи безпосередньо у особи, яку представляють. Відсутність у особи, яку представляють юридично значущої волі або наявність вад волі у момент уповноваження представника (видача довіреності недієздатною особою, під впливом обману, помилки тощо) тягнуть за собою нікчемність або оспорюваність правочину за повноваженням, а разом з тим і правочину, вчиненого представником. Для виникнення у особи, яку представляють тих або інших юридичних наслідків необхідне також волевиявлення представника, оскільки саме він вчиняє правочин, але у волевиявленні представника при добровільному представництві виражається і воля того, від імені кого він виступає.

\section{Література:}

1. Цивільний Кодекс України: Закон України від 16 січня 2003 року № 435-IV. URL : https://zakon.rada.gov.ua/laws/show/435-15 (дата звернення 19.04.2021).

2. Сімейний кодекс України: Закон України від 10 січня 2002 року № 2947-III. URL : https://zakon.rada.gov.ua/laws/show/2947-14\#top (дата звернення 19.04.2021). 